\title{
Globalisasi Hooliganisme terhadap Suporter Sepak Bola di Indonesia
}

\author{
Firman Hendika dan Nuraeni \\ Universitas Padjadjaran
}

\begin{abstract}
ABSTRAK
Tulisan ini ditujukan untuk memberikan gambaran mengenai perkembangan budaya Hooliganisme dalam suporter sepak bola di Indonesia. Hooliganisme merujukpada kecenderungan kelompoksuporter sepakbola melukan tindakan nakal dan merusak, seperti berkelahi, vandalisme, dan melakukantindakanintimidasi.Belakanganini, tindakan hooliganisme marak ditemukan di antara para suporter klub sepak bola di Indonesia yang mencirikan tindakan para hooligan asal Inggris. Dari latar belakang tersebut, artikel ini berfokus pada bagaimana globalisasi hooliganisme berpengaruh kepada kelompok suporter klub sepak bola di Indonesia. Analisis penulis menggunakan pendekatan kualitatif dengan metode deskriptif. Data yang dianalisis adalah hasil studi literatur serta wawancara para ahli yang relevan dengan artikel yang penulis lakukan. Hasil analisis penulis menunjukkan bahwa globalisasi telah mempercepat penyebaran paham budaya hooliganisme terhadap kelompok suporter sepak bola di Indonesia. Banyak kelompok suporter di Indonesia yang merasa lebih keren ketika meidentifikasikan diri mereka sebagai seorang hooligan. Tindakan-tindakan nakal dan kriminal dianggap sebagai suatu hal yang harus dilakukan untuk memperkuat eksistensi kelompok mereka diantara kelompok lainnya.
\end{abstract}

Kata-kata Kunci: Hooliganisme, Globalisasi, Budaya, Media

This paper is aimed to provide an overview of the development of Hooliganism in football fans in Indonesia. Hooliganism refers to the tendency of football supporters groups to commit naughty and destructive actions, such as fighting, vandalism, and acts of intimidation. Lately, acts of hooliganism are rife among supporters of football clubs in Indonesia that characterize the actions of British hooligans. This article then focuses on how the globalization of hooliganism influences supporters of football clubs in Indonesia. The author's analysis uses a qualitative approach with descriptive methods. The data analyzed are the results of literature studies and expert interviews that are relevant to the topic of the article. The results indicate that globalization has accelerated the spread of hooliganism towards football supporters in Indonesia. Many groups of supporters in Indonesia feel cooler when they identify themselves as a hooligan. Naughty and criminal acts are considered as something that must be done to strengthen the existence of their group among other groups.

Keywords: Hooliganism, Globalization, Culture, Media 
Hooliganisme diartikan sebagai suatu paham terhadap suatu budaya yang merujuk pada apa yang secara luas dianggap sebagai perilaku nakal dan merusak oleh kelompok suporter sepakbola (hooligan), seperti berkelahi, vandalisme, dan melakukan tindakan intimidasi. Hooliganisme sendiri pertama berkembang di tanah Inggris dan disebut dengan "The English Disease" oleh otoritas pemerintah di sana (Deriemaeker \& Maere 2016, 3). Salah satu tragedi yang melibatkan para hooligan terjadi pada tanggal 29 Mei 1985, ketika berlangsungnya babak Final European Cup (Liga Champions Eropa) 1985 yang mempertemukan Liverpool dan Juventus. Dalam tragedi ini, terjadi baku hantam di antara para suporter kedua kesebelasan terlibat, hingga tribun stadion tidak mampu menopang beban suporter dan berujung runtuh. Tragedi ini memakan 39 orang yang sebagian besar merupakan suporter Juventus harus menjadi korban; dan lebih dari 600 orang mengalami luka-luka (Steen 2016, 263).

Selanjutnya, tragedi paling terkenal yang pernah terjadi melibatkan tindakan brutal para hooligan, bertajuk "Hillsbourg disaster". Tragedi tersebut terjadi pada tanggal 15 April 1989, dimana di tengah berlangsungnya pertandingan babak semi final Piala FA (The Football Association Challenge Cup) mempertemukan Liverpool dan Nottingham Forest di Hillsborough Stadium, markas kesebelasan Sheffield Wednesday (Scraton 2009, 41). Dalam tragedi tersebut, 96 nyawa suporter Liverpool melayang dan 766 orang luka-luka akibat runtuhnya tribun stadion yang disinyalir diakibatkan oleh pendukung Liverpool yang memaksa masuk ketika semua tribun sudah penuh. "Hillsbourg disaster" merupakan tragedi sepakbola terbesar di Inggris yang dan menjadi inspirasi bagi logo baru klub Liverpool sebagai bentuk penghormatan bagi para korban (Scraton 2009, 79). Pasca "Hillsbourg disaster", Liverpool menambahkan dua buah obor pada kedua sisi logo tim sebagai bentuk simbolis penghormatan terhadap tugu peringatan "Hillsbourg disaster" yang terdapat di luar Stadion Anfield. Tugu tersebut terletak di luar Stadion Anfield sebagai bentuk peringatan 96 korban tragedi yang merupakan korban terhadap tragedi tersebut. Dalam dunia sepakbola, kelompok-kelompok suporter yang melakukan tindakan tersebut dikenal dengan kelompok ultras atau yang lebih dikenal sebagai hooligan di daratan Inggris.

Belakangan ini, budaya tersebut muncul dan menjadi ciri khas baru dalam suporter sepakbola di Indonesia. Seperti kasus yang melibatkan kelompok suporter Persija Jakarta, 'The Jakmania', melawan kelompok suporter sepakbola Persib Bandung, 'Bobotoh'. Pada pertandingan lanjutan Liga 1 2018/2019 hari Minggu, 23 September 2018 kedua klub tersebut dipertemukan dan berujung 
kepada suatu insiden pengeroyokan yang memakan seorang korban yang merupakan suporter klub Persija Jakarta. Haringga Sirla, seorang pemuda asal ibu kota Jakarta nekat berangkat ke Bandung untuk menyaksikan laga tersebut. Akan tetapi, dibuktikan bahwa sebelum laga tersebut dimulai, pihak kepolisian telah menghimbau kepada 'The Jakmania' untuk tidak menghadiri pertandingan yang dilaksanakan diStadion Gelora Bandung Lautan Api (GBLA) tersebut. Namun, Haringga tetap bersikukuh untuk datang memberikan dukungan secara langsung, hingga akhirnya harus berakhir tragis karena beliau menjadi korban dualisme suporter 'Bobotoh' dan 'The Jakmania' (Simbolon 2018). Namun, Haringga bukanlah korban pertama dari pertikaian antar suporter di tanah air. Masih melibatkan pihak yang sama, antara 'The Jakmania' dan 'Bobotoh'. Pada 22 Juli 2017, seorang 'Bobotoh' bernama Ricko Andrean Maulana menjadi korban perselisihan antar-suporter tersebut. Ricko, seorang 'Bobotoh', harus tewas di tangan Bobotoh lainnya karena berusaha melerai keributan yang terjadi antara 'Bobotoh' yang mengeroyok 'The Jakmania' yang menghadiri pertandingan tersebut. (Ramdhani 2017)

Kedua kasus tersebut merupakan bukti kecil dari banyaknya kasus pengeroyokan yang terjadi akibat tensi antar-kelompok suporter sepakbola di Indonesia. Sentimen suporter sepakbola di Indonesia didasari oleh adanya sentimen kedaerahan yang menjadi dasar terbentuknya suporter di Indonesia. Muncul identifikasi berdasarkan asal-usul kedaerahan yang mencirikan seseorang ke dalam sebuah kelompok. Identifikasi yang didasari atas perbedaan ras dan etnis di sini menjadi sasaran diskriminasi yang paling sering dan lazim dijumpai di masyarakat. Atas tindakan diskriminasi tersebut, muncul pemahaman-pemahaman rasis yang muncul antar-suporter di Indonesia.

Rasisme adalah fenomena yang diwariskan oleh narasi-narasi yang ada di masyarakat. Dalam studi mengenai identitas, terdapat pendekatan yang dikenal dengan psychocultural narrative. Pendekatan ini merupakan suatu pandangan dunia bersama yang berakar dalam yang membantu kelompok-kelompok memahami kehidupan mereka sehari-hari dan memberikan penjelasan psikologis yang bermakna tentang hubungan suatu kelompok dengan kelompok lain, berdasarkan tindakan dan motif apa yang mereka maksudkan (Ross 2007, 30) Psychocultural narrative merupakan kumpulan interpretasi ke dalam catatan asal-usul, sejarah, dan konflik kelompok dengan pihak outgroup, termasuk perilaku simbolis dan ritualnya. Interpretasi dari narasi ini adalah inti dari sistem makna dan identitas bersama yang mendefinisikan 
komunitas budaya (Ross 2007, 24). Peristiwa atau pengalaman di masa yang lalu juga menjadi metafora dan pelajaran bagi kelompok tersebut, sedangkan narasi menjadi memori kolektif. Memori kolektif adalah memori yang dialami oleh sekelompok orang atau komunitas. Pemahaman hooliganisme perlu didasarkan dengan apa yang dimaksud sebagai hooligan. Hooligan merupakan suatu kelompok suporter yang terorganisir secara sosial atau dilembagakan dan terlibat dalam berbagai tindak kekerasan secara kompetitif, terutama dengan kelompok hooligan lainnya (Spaaij 2005, 1). Belakangan ini, budaya Hooliganisme tersebut tengah menyebar dalam kelompok-kelompok suporter yang ada di Indonesia. Penyebaran tersebut didorong dengan adanya globalisasi yang mempermudah akses terhadap informasi mengenai hooliganisme itu sendiri, baik melalui media sosial ataupun film yang mengangkat cerita hooligan itu sendiri.

Globalisasi mempermudah masyarakat Indonesia untuk menerima dan meniru setiap kebudayaan dan gaya hidup yang berasal dari luar negeri, terutama dengan adanya globalisasi media. Hal tersebut merupakan aspek yang paling berpengaruh dalam penetrasi teknologi media komunikasi yang semakin mendunia dan menglobal. Hampir semua negara di dunia, termasuk di Indonesia, memiliki setidaknya beberapa orang yang menggunakan internet dan televisi satelit (Jan 2009, 67). Para suporter sepakbola di Indonesia mulai meniru segala tindakan yang mereka temui melalui internet dan televisi dan menerapkannya dalam cara memberikan kepada dukungan kepada klub yang mereka dukung. Inggris sebagai negara budaya hooliganisme berasal, memiliki berbagai kultur budaya mengenai sepakbola yang cukup kental diantar negaranegara lainnya. Indonesia sebagai negara yang juga memiliki basis kelompok suporter sepak bola fanatik yang cukup besar di dunia, juga mulai berkiblat ke Inggris dalam memunculkan gaya dalam memberikan dukungan bagi klub sepakbola kesayangan mereka. Hal tersebut dipermudah dengan adanya internet dan televisi untuk penyampaian dan penerimaan informasi di Indonesia. Oleh sebab itu, artikel ini mencoba untuk menggambarkan bagaimana budaya Hooliganisme asal Inggris dapat berkembang dan memberikan pengaruh bagi para suporter sepakbola yang ada di Indonesia.

\section{Globalisasi dalam Hubungan Internasional}

Globalisasi merupakan suatu istilah yang tidak asing lagi bagi masyarakat internasional dari dua dekade terakhir ini. George Ritzer mendefinisikan proses global sebagai transplanetary process or set of processes involving increasing liquidity and the growing 
multidirectional flows of people, objects, places and information as well as the structures they encounter and create that are barriers to, or expedite, those flows (Ritzer 2010). Globalisasi dapat di analisa melalui beberapa konsep, yaitu solids (padat), liquids (cair), gases (gas), flows (mengalir), heavy (berat), light (ringan), weightless (tanpa bobot). Sebelum memasuki era globalisasi penyampaian informasi cenderung berbentuk "padat". Pada era ini, alat-alat yang digunakan masih cenderung berfungsi di satu tempat saja sehingga bisa dibilang menghambat pergerakan dan penyampaian informasi dalam aktivitas manusia. (Ritzer 2010, 2-4).

Setelah melewati solids era, selanjutnya manusia masuk ke liquids era yang mana teknologi informasi dan transformasi mengalami perkembangan yang jauh lebih baik dari pada solids era. Pada era ini, meskipun teknologi memang sudah mulai berkembang, dan yang paling terasa adalah dengan munculnya internet. Akan tetapi, masih ada orang-orang yang memang merasa lebih nyaman menggunakan teknologi pada solids era, seperti masih banyaknya orang-orang tua yang membaca berita melalui koran daripada melalui media internet. Hal tersebut diakibatkan oleh adanya cultural shock dalam masyarakat yang belum siap untuk menerima adanya perkembangan teknologi yang lumayan cepat pada saat itu. Cultural shock tersebut terjadi diakibatkan oleh berbagai faktor yang belum siap diterima oleh masyarakat (Wingkelman 1994, 121). Istilah flows yang berhubungan dengan liquids era mulai berkembang bersamaan dengan teknologi, transportasi maupun informasi yang digambarkan dengan proses "melting" yang berhasil tersebar hingga seluruh penjuru dunia. Namun ada dampak buruk dari proses flows karena menjadi bumerang tersendiri bagi mereka yang terlibat langsung, seperti dengan bermunculannya para imigran ilegal akibat semakin bebasnya globalisasi. Selanjutnya masyarakat memasuki gases era, yang mana pada era tersebut mengikuti tuntutan mobilitas masyarakat yang semakin tinggi. Pada era ini, komunikasi semakin mudah dengan adanya $e$-mail dan sosial media lainnya (Ritzer 2010, 5-7). Memang tidak bisa dipungkiri jika adanya perkembangan komunikasi dengan adanya $e$-mail semakin mempercepat penyebaran dari globalisasi hingga ke seluruh penjuru dunia.

Globalisasi juga dapat dianalisis dengan istilah heavy, light, dan weightless. Istilah tersebut menggambarkan dari objek pada saat itu, contohnya pada masa masyarakat industrial termasuk ke dalam heavy karena menggunakan teknologi yang tidak terlalu efisien. Pada masa sebelum berkembangnya era globalisasi, banyak literatur dunia yang dibuat dalam buku yang bahkan memiliki 
ketebalan hingga ribuan halaman. Sebagai contoh adalah the Original Gutenber bible yang dicetak dalam dua volume yang mana mencapai 1.400 halaman. Buku ini juga dicetak di atas kertas yang memiliki ketebalan yang lumayan, sehingga menjadikan buku ini sangat berat dan tidak efisien untuk dibawa ke mana-mana (Ritzer 2010, 11). Kemudian teknologi tersebut berkembang menuju light dan akhirnya mencapai globalisasi weightless, yakni keika teknologi yang digunakan sudah canggih dan efisien sehingga mempermudah masyarakat dalam melakukan aktivitasnya . Hal tersebut bisa kita lihat dengan bermunculannya teknologi-teknologi yang makin hari semakin berukuran lebih kecil. Seperti dalam mencari bahan belajar, kini tidak perlu lagi menggunakan buku-buku yang berukuran besar dan sangat berat. Hal tersebut tentu sungguh tidak efektif dan sangat tidak efisien. Penggunaan teknologi seperti laptop, smartphone, dan perangkat gawai lainnya, pada saat ini lebih banyak digunakan ketimbang harus menggunakan alat-alat yang berbobot berat tadi. Saat ini, penggunaan $e$-book menjadi primadona di kalangan pelajar. Selain mudah untuk dibaca dimana-mana, e-book juga sangat mudah untuk didapatkan.

Dalam perkembangannya, globalisasi telah mengalami beberapa fase yang disebut sebagai gelombang globalisasi. Menurut Gotan Therborn, ada enam gelombang dalam globalisasi yang mana dalam setiap gelombangnya, terdapat perbedaan proses perubahan dunia yang sangat cepat dan dinamis. Gelombang pertama merupakan awal kemunculan peradaban-peradaban di dunia dengan munculnya difusi dan pengaruh yang cukup kuat dari dunia agama (Therborn 2000, 158). Gelombang kedua ditandai dengan dimulainya penjelajahan dunia melalui jalur laut serta dimulainya gelombang kolonisasi yang dilakukan oleh bangsa Eropa pada akhir abad ke-15. Pada gelombang ini, seorang penjelajah asal Spanyol, Christopher Columbus menemukan benua yang sekarang dikenal dengan sebutan benua Amerika pada 3 Agustus 1492 (History 2009). Selepas penemuan benua Amerika tersebut, dimulai migrasi besar bangsa-bangsa Eropa menuju Amerika untuk memulai kehidupan baru di sana. Gelombang ketiga adalah gelombang yang mencatat untuk pertama kalinya peperangan dalam skala global terjadi. Hal tersebut diawali dengan adanya persaingan dalam memberikan pengaruh antar negara-negara di Eropa, seperti persaingan yang terjadi antara Inggris dan Perancis dalam mengakumulasi pengaruh negara-negara anggota aliansinya (Therborn 2000). Persaingan antara Inggris dan Perancis tidak hanya terasa di Eropa saja, bahkan dirasakan hingga ke Amerika Utara, Karibia, dan India. Pada masa ini, juga dikenal dengan penaklukan Mesir oleh Napoleon Bonaparte, yang meluaskan pengaruh perang yang bersifat intra- 
European menuju negara dengan kekuasaan kerajaan Islam yang kuat (Therborn 2000, 161).

Dalam peralihan dari gelombang keempat menuju gelombang kelima, penggunaan emas sebagai alat tukar dalam bertransaksi mulai ditinggalkan. Hal tersebut disebabkan oleh terjadinya krisis pasca-Perang Dunia I. Pada era deglobalisasi ini, terjadi partikularisme negara dan kelompok etnis (Therborn 2000, 162). Partikularisme tersebut mendorong munculnya Perang Dunia II yang lingkup kejadiannya jauh lebih luas. Tidak hanya berpusat di benua Eropa saja, akan tetapi meluas hingga ke wilayah Pasifik yang menjadi tempat kontestasi pertempuran antara Jepang dan Amerika Serikat. (Therborn 2000, 162). Berjalannya Perang Dunia II membawa dunia masuk ke dalam gelombang globalisasi kelima yang mana gelombang tersebut merupakan masa akhir dari perang dan menghasilkan Amerika Serikat dan Uni Soviet keluar sebagai negara pemenang dalam perang. Kedua negara pemenang tersebut muncul sebagai negara superpower yang mendorong kedua negara tersebut dalam perlombaan akumulasi pengaruh mereka ke seluruh dunia. Perlombaan tersebut kerap dikenal sebagai Perang Dingin yang merupakan sesuatu yang tidak bisa dihindari. Perbedaan ideologi antara kedua negara menjadi faktor utama pembentukan kedua blok tersebut. Amerika Serikat dengan paham liberalnya melawan Uni Soviet dengan paham komunisnya, meningkatkan tensi dunia dalam Perang Dingin. Kedua negara berlomba untuk meningkatkan kekuatan militer dan politiknya yang secara tidak langsung berpengaruh terhadap globalisasi teknologi militer di dunia. Salah satu teknologi tercanggih yang dihasilkan dari Perang Dingin adalah munculnya pesawat ulang alik sebagai hasil kontestasi kedua blok dalam Space Race (History 2010).

Gelombang keenam menandai pusat globalisasi yang berubah menjadi ekonomi dan budaya. Pada masa ini, kembali terjadi migrasi besar dengan motif yang berbeda dari sebelumnya. Migrasi sebagian besar dilakukan oleh imigran yang berasal dari negaranegara Selatan menuju Utara. Hal tersebut disebabkan oleh kurangnya tenaga kerja di pusat negara kapitalis (Therborn 2000, 163). Migrasi ini, berhasil memunculkan akulturasi budaya dan menghasilkan budaya-budaya baru di dunia, seperti wilayah Eropa Barat yang pada awalnya sebagian besar berpenduduk orang AngloSaxon, namun saat ini orang banyak dihuni orang Hispanic dan Asia juga banyak dijumpai di sana (Therborn 2000,163). Pada masa ini, informasi internasional sangat mudah diakses, terutama dengan ditemukannya internet. Inovasi berlanjut dengan kemunculan alat komunikasi yang lebih canggih dari sebelumnya, seperti handphone 
yang berhasil menghubungkan setiap individu meskipun berada di tempat yang berjauhan. Pada abad ke-20, bahasa Inggris berhasil menyebar ke seluruh penjuru dunia dan menjadi bahasa internasional. Kemajuan teknologi transportasi juga semakin terasa daripada sebelumnya. Seperti dalam artikel yang sedang penulis lakukan, penulis bermaksud untuk melihat bagaimana pengaruh dari adanya globalisasi terhadap persebaran pengaruh hooliganisme terhadap para suporter sepakbola di Indonesia.

\section{Globalisasi dalam Olahraga}

Proses globalisasi adalah suatu hal yang bersifat mengglobal dan telah masuk ke dalam berbagai aspek kehidupan, termasuk dalam bidang olahraga. Sudah menjadi hal yang umum bahwa olahraga kini telah menjadi suatu fenomena yang bersifat universal. Adanya penyelenggaraan Olimpiade, musim semi maupun musim dingin, Piala Dunia FIFA, dan Commonwealth Country Competitions merupakan contoh dari adanya globalisasi di dalam olahraga. Dalam kondisi tersebut, setiap negara yang terlibat dalam setiap penyelenggaraan tersebut dapat saling memberikan pengaruh dan berdampak pada pandangan negara lainnya. Di abad ke-21, bukan merupakan hal yang sulit bagi kita untuk dapat mengetahui interaksi yang terjalin antar manusia. Termasuk di dalam kegiatan penyelenggaraan pesta olahraga, yang memerlukan adanya global vision (Ghafouri, Mirzaei, Hums, \& Honavar 2009, 3).

Dalam tulisan karya George Wright yang berjudul "Sport and Globalization", menyebutkan jika Amerikanisasi merupakan salah satu dari contoh adanya proses globalisasi di dalam olahraga (Wright 1999, 18). Amerikanisasi merupakan suatu proses penyebaran pengaruh budaya dan bisnis Amerika Serikat di negara lainnya, seperti dalam media, makanan, bisnis, budaya popular, teknologi, dan politik. (Wright 1999, 18). Amerikanisasi dan olahraga dapat dicontohkan dengan komersialisasi jaket dari tim NFL, baju olahraga (jersey) dari tim San Jose Sharks, dan sepatu Nike Air Jordan yang marak digunakan di hampir seluruh negara di dunia (Wright 1999, 18). Selain adanya Amerikanisasi, terdapat pandangan lain yang membenarkan adanya globalisasi yang terjadi dalam olahraga. Jean Harvey dan Ganevieve Rail menyatakan jika olahraga pada era modern selalu bergerak di dalam ekonomi global dan hal tersebut turut mendorong perkembangan olahraga untuk mengglobal pula. Pengaruh dimensi politik, ekonomi dan kebudayaan telah menimbulkan proses homogenisasi olahraga melalui komodifikasi bentuk dari olahraga yang memiliki unsur kebaratan. Olahraga berkontribusi terhadap globalisasi dengan 
membantu pengembangan konsumsi massal yang bersifat global (Wright 1999, 18).

Dalam artikel ini, penulis lebih menekankan pada globalisasi yang terjadi di cabang olahraga sepak bola. Sepakbola merupakan cabang olahraga paling populer di dunia sejak akhir abad ke-19, serta dengan adanya difusi internasional yang dilakukan oleh Inggris. Diperkirakan sekitar 33.4 miliar orang menyaksikan final Piala Dunia FIFA. Angka tersebut merupakan angka yang sangat besar bagi penonton suatu acara olahraga (Giulianotti \& Robertson 2004, 545). Sepakbola di era modern merupakan bentuk dari globalisasi yang paling terlihat dalam olahraga. Sepakbola modern merupakan bagian dari intensifikasi konektivitas yang terjalin antar-budaya, terdapat tingkat mobilitas pemain dan suporter sepak bola yang tinggi dari satu negara ke negara lain yang mana pemain-pemain sepakbola membawa budaya khas dari negara asal mereka (Vreeswijk 2016, 12). Pada tahun 2005, lebih dari 50\% pemain asing di Eropa Barat merupakan imigran. Hal tersebut merupakan contoh dari begitu terasanya dampak dari globalisasi melalui kegiatan migrasi internasional dalam sepakbola. Sepakbola kini menjadi salah satu komoditas penghasilan utama yang mulai disandingkan dengan pekerjaan lainnya, tetapi dengan adanya hal tersebut sering terjadi penyalahgunaan dikarenakan kurang ketatnya aturanaturan dibandingkan dengan profesi lain. Dikarenakan hal tersebut, beberapa federasi sepakbola di beberapa negara mengeluarkan kebijakan yang bertujuan untuk mengatur jumlah pemain migran di negara mereka. Salah satu kebijakan yang terbentuk berada di Inggris dengan kebijakan homegrown player rules. Melalui kebijakan ini setiap klub peserta English Premier League diharuskan mendaftarkan delapan pemain dengan status homegrown dari dua puluh lima pemain yang masuk ke dalam squad list sebelum dimulainya musim kompetisi yang baru (Henderson 2011, 266).

\section{Hooliganisme di Inggris}

Istilah hooliganisme sendiri baru muncul pada akhir abad ke-18 di Inggris, terutama pada tahun 1898. Kemunculan ditandai ketika para suporter muda di Inggris secara liar melakukan perilaku kekerasan dan destruktif mulai terbentuk secara teratur di pertandingan sepak bola (Akran, Sejarah Hooliganisme di Inggris dan Indonesia 2019). Istilah hooligan pertama kali muncul di dalam surat kabar lama Inggris yang menyebutkan istilah "Houlihan". Houlihan sendiri merupakan nama dari sebuah keluarga asal Irlandia yang dianggap sebagai sebuah lakon oleh The O'Hooligan Boys di ruang musik Plumstead. Para hooligan dituliskan sangat identik dengan ciri- 
ciri penampilan "Teddy Boy", "Mod" dan "Skinhead", serta sangat popular di kalangan kelas pekerja di Inggris (Deriemaeker \& Maere 2016, 2). Pada awalnya, tindakan kekerasan yang dilakukan oleh para hooligan ditunjukkan terhadap para pemain. Namun, seiring berjalannya waktu, pada tahun 1960-an, serangan mulai ditunjukkan terhadap suporter dari klub lainnya dan terhadap polisi. Tindakan penyerangan tersebut ditandai dengan kemunculan "Youth Ends", kelompok suporter yang berisikan pemuda kelas pekerja yang memiliki ciri khas menggunakan pakaian berlabel designer. Hal tersebut membuat polisi lebih sulit saat mengidentifikasi kelompok hooligan (Deriemaeker \& Maere 2016, 3).

Tindakan para hooligan tersebut kemudian semakin meluas ke dalam ranah perebutan daerah kekuasaan, tepatnya ketika setiap suporter saling berlomba dalam mengambil alih wilayah kekuasaan masingmasing dengan berbagai cara hingga melakukan kekerasan. Periode tersebut sering disebut dengan "The English Disease" (Deriemaeker \& Maere 2016, 4). Peristiwa "The English Disease" terjadi pada tahun 1983, ketika 150 orang suporter klub Tottenham Hotspurs ditangkap kepolisian Luxembourg setelah terlibat dalam kerusuhan yang terjadi di Rotterdam. Dalam pertandingan tersebut, para hooligan Spurs mengamuk dan melakukan penusukan terhadap beberapa suporter Feyenord Rotterdam. Meskipun pada pertandingan tersebut Spurs berhasil meraih kemenangan 4-0 atas Feyenord, namun Spurs gagal untuk melaju ke European Championship tahun 1984. Oleh sebab itu, klub-klub asal Inggris mendapatkan larangan bertanding di kompetisi Eropa untuk beberapa tahun (Cawthorne 2012, 12). Fenomena tersebut merupakan salah satu dari berbagai kasus berdarah yang diakibatkan oleh tindakan anarkis para hooligan Inggris. Pada 29 Mei 1985, kembali terjadi tragedi kelam dalam sejarah olahraga sepak bola, dimana terjadi bentrokan dalam pertandingan final European Cup 1985 yang mempertemukan Liverpool dan Juventus. Suporter kedua tim tersebut mengakibatkan salah satu tribun dari Heysel Stadium rubuh dan menimpa ratusan penonton yang sebagian besar merupakan pendukung dari kesebelasan Juventus. Dalam kejadian yang dikenal sebagai "Heysel Disaster" tersebut, setidaknya 39 pendukung Juventus menjadi korban (Carnibella, et al. 1996, 117).

Namun, kejadian tersebut bukan menjadi tragedi terakhir yang diakibatkan oleh tindakan anarkis para hooligan Inggris. Pada 15 April 1989, suatu tragedi terjadi di tengah berlangsungnya pertandingan babak semi final Piala FA yang mempertemukan Liverpool dan Nottingham Forest di Hillsborough Stadium, markas kesebelasan Sheffield Wednesday (Scraton 2009, 41). Tragedi yang 
dikenal dengan "Hillsborough Disaster" ini berawal dari tribun stadion yang saat itu digunakan dalam pertandingan dan tidak mampu menampung seluruh penonton yang membludak, terutama pendukung dari klub Liverpool. Terdapat lebih dari 24.000 pendukung Liverpool yang tidak dapat ditampung oleh tribun penonton, sehingga mengakibatkan tribun berdiri Hillsborough Stadium, Lepping Lane Stand, runtuh karena tidak mampu lagi menahan beban penonton. Para suporter banyak yang terhimpit tumpukan manusia yang berjatuhan. Hal tersebut diperparah oleh dihalanginya ruang gerak mereka oleh pagar besi di hadapan mereka. Setidaknya sekitar 96 nyawa suporter Liverpool melayang dan 766 orang luka-luka akibat runtuhnya tribun stadion yang disinyalir diakibatkan oleh pendukung Liverpool yang memaksa masuk ketika semua tribun sudah penuh (Scraton 2009, 79). Akibat berbagai tragedi tersebut, Inggris dianggap sebagai negara yang menjadi sumber masalah utama hooliganisme di dunia, khususnya di Eropa pada saat itu. Akibat dari tindakan para hooligan Inggris tersebut, klub-klub asal Inggris sering mendapatkan larangan untuk bertanding pada level Eropa dan dunia (Carnibella, et al. 1996, 112).

\section{Masuknya Hooliganisme di Indonesia}

Budaya kekerasan dalam sepak bola dalam konflik suporter di Indonesia tidak terlepas dari perspektif budaya permusuhan suporter di Eropa (Akran 2016). Iklim suporter sepak bola di Indonesia sangat transparan dengan menunjukkan atribut kesebelasan sepak bola kebanggaan, baik laga home maupun away. Dukungan suporter selama pertandingan diperkaya dengan adanya koreografi di tribun dan diiringi dengan adanya nyanyian dari para suporter. Duplikasi terhadap budaya yang berasal dari luar sangat cepat terjadi di Indonesia. Globalisasi kini telah mempermudah percepatan penyebaran arus informasi di seluruh penjuru dunia, termasuk di Indonesia. Masyarakat dengan mudah dapat menerima informasi yang bahkan berasal jauh dari tempat ia tinggal. Duplikasi terhadap budaya luar sangat cepat sekali diserap oleh sebagian besar masyarakat Indonesia. Salah satunya karakter suporter sepak bola di Indonesia. Mereka melihat hooliganisme di luar negeri kemudian mencoba menerapkan cara pandang sebagai suporter (Akran 2019).

Hooliganisme menjadi populer di Indonesia sejak munculnya film 'Green Street Hooligans' pada tahun 2005 (Aunnurahman 2019). 'Green Street Hooligans' sendiri merupakan sebuah film yang menggambarkan mengenai kefanatikan kelompok hooligan yang ada di Inggris yang menyajikan tindakan-tindakan kekerasan yang dilakukan dalam mendukung tim kesayangan mereka. (Ayuningtyas 
2009, 139). Media kemudian memiliki peran yang sangat besar dalam menyebarnya budaya hooliganisme di dunia, termasuk di Indonesia. Sejak tahun 1960-an, media mulai menyoroti tindakan para penonton sepak bola, termasuk tindakan kekerasan yang terjadi. Akibatnya, liputan media mengenai tindakan kriminal para suporter menyebar dengan sangat cepat dan kerap kali menjadi berita utama (headlines) dalam beberapa surat kabar (Frosdick \& Marsh 2005, 123). Tragedi tindakan kekerasan suporter yang menjadi berita utama adalah "Hillsborough Disaster" dan "Heysel Disaster" yang menyebar melalui media dan sekaligus memperkenalkan hooliganisme di seluruh penjuru dunia. Sejak saat itu, budaya hooliganisme semakin berkembang di Indonesia. Banyak suporter klub sepak bola di Indonesia mulai mengikuti gaya para hooligan Inggris ketika menonton langsung pertandingan di stadion. Gaya berpakaian menjadi salah satu hal yang paling terlihat jika banyak suporter sepak bola di Indonesia meniru gaya berpakaian para hooligan di Inggris. Gaya berpakaian casual dengan ciri khas pakaian brand terkenal seperti jaket parka, polo shirts, sepatu casual, topi, dan buffs menjadi hal yang paling sering ditiru oleh suporter sepak bola di negara yang meniru hooligan Inggris. (Hopkins \& Treadwell 2014).

Masih banyak suporter klub sepak bola di Indonesia yang melakukan duplikasi tanpa adanya proses pengetahuan dan penyaringan yang benar (Akra 2019). Banyak individu maupun kelompok suporter di Indonesia yang mengambil sisi negatif dari hooliganisme itu sendiri, seperti sisi kultur militansinya ketika memberikan dukungan. Mereka dengan bangga menggunakan identitasnya sebagai hooligan dan tidak segan-segan untuk melakukan tindakan anarkis yang bahkan bisa menelan korban jiwa. Tindakan kekerasan suporter di Indonesia telah merenggut beberapa nyawa. kegengsian suporter di tribun menjadi salah satu faktor utama terjadinya perkelahian di stadion. Indonesia telah memiliki beberapa kasus kekerasan suporter cabang olahraga sepakbola beberapa waktu terakhir. Kasus pertama melibatkan kelompok suporter Persija Jakarta, 'The Jakmania', melawan kelompok suporter sepak bola Persib Bandung, 'Bobotoh'. Pada pertandingan lanjutan Liga 1 2018/2019 hari Minggu, 23 September 2018 yang mempertemukan kedua tim tersebut, terjadi suatu insiden pengeroyokan yang memakan seorang korban yang merupakan suporter klub Persija Jakarta. Haringga Sirla, seorang pemuda asal ibu kota Jakarta nekat berangkat ke Bandung untuk menyaksikan laga tersebut. Sejatinya, telah terdapat himbauan dari pihak kepolisian bagi para 'The Jakmania' pada awal laga untuk tidak menghadiri pertandingan yang dilaksanakan di Stadion Gelora Bandung Lautan Api (GBLA) tersebut. Namun, Haringga 
tetap bersikukuh datang untuk memberikan dukungan secara langsung. Setelah menempuh perjalanan beberapa jam, ia pun tiba di Bandung pukul 13.00. Namun naas bagi Haringga, sesampainya di Stadion GBLA, ternyata pada saat yang bersamaan, di kawasan halaman Stadion GBLA, telah ramai oleh aksi beberapa oknum 'Bobotoh' yang tengah melakukan sweeping Kartu Tanda Peduduk (KTP) dan Haringga pun menjadi sasaran razia dan identitasnya sebagai warga Jakarta pun diketahui melalui kartu identitas anggota 'The Jakmania' yang ia bawa. Mengetahui hal tersebut, Haringga pun menjadi korban pengeroyokan oleh oknum 'Bobotoh' hingga akhirnya tewas secara mengenaskan (Simbolon 2018).

Haringga bukanlah korban pertama dari pertikaian antar-suporter di tanah air. Korban selanjutnya masih melibatkan dua kelompok suporter yang sama, antara 'The Jakmania' dan 'Bobotoh'. Pada 22 Juli 2017, seorang 'Bobotoh' bernama Ricko Andrean Maulana menjadi korban perselisihan antar-suporter tersebut. Ricko yang aslinya merupakan seorang 'Bobotoh' tewas di tangan suporter 'Bobotoh' lainnya karena berusaha melerai keributan yang terjadi antara 'Bobotoh' yang mengeroyok 'The Jakmania' yang menghadiri pertandingan tersebut. Rickoyang sudah dianggap tidak mengenakan atribut Persib, justru ikut dianggap sebagai anggota 'The Jakmania' dan menjadi korban oknum 'Bobotoh' yang tidak bertanggung jawab. Sebenarnya, sebelum dipukuli Ricko sempat menunjukkan KTP dengan domisili kota Bandung. Namun dengan banyaknya massa yang sudah emosi, pembelaan yang ia lakukan pun berakhir dengan sia-sia. Ricko tetap dipukuli dan menjadi bulan-bulanan oknum suporter hingga akhirnya babak belur dan tidak sadarkan diri. Ricko pun dinyatakan meninggal dunia setelah sempat dilarikan ke Rumah Sakit AMC Cileunyi (Ramdhani 2017).

Jika kita lihat dari berbagai kasus kekerasan suporter di Indonesia di atas, dapat kita amati jika motif dari tindakan kekerasan tersebut biasanya didasari oleh rasa tidak suka yang diakibatkan oleh tensi kedaerahan. Pada kedua kasus di atas, melibatkan dua kelompok suporter dari dua daerah yang berbeda, Persib Bandung dengan mayoritas suporter berasal dari Jawa Barat serta Persija Jakarta dengan mayoritas suporter berasal dari D.K.I. Jakarta. Tindakan main hakim sendiri dalam kasus Haringga Sirla merupakan bukti paling nyata tensi suporter di Indonesia yang diakibatkan oleh perbedaan daerah. Dengan melakukan sweeping dan menemukan KTP Haringga yang berdomisili di Jakarta, sontak para suporter Persib Bandung pun langsung mengeroyok Haringga yang dianggap sebagai seorang pendukung Persija Jakarta berdasarkan data diri dimilikinya. Kedua narasumber mengatakan jika hooliganisme dari 
Inggris cukup memberikan pengaruh terhadap gaya serta perilaku para suporter sepak bola di Indonesia, kenyataannya tindakan anarkis para suporter di Indonesia memang sudah ada tanpa harus mendapatkan pengaruh dari budaya hooliganisme. Namun, dengan masuknya budaya hooliganisme di antara suporter sepak bola di Indonesia, cukup memberikan warna lain dalam suporter sepak bola di Indonesia. Seperti penggunaan flare dalam pertandingan dan bahkan penggunaan bom molotov sebagai senjata yang digunakan ketika berkelahi.

Berbagai upaya telah dilakukan pihak berwenang untuk dapat meredam tindakan anarkis dari para hooligan di Indonesia. Seperti melakukan sweeping terhadap setiap suporter yang hendak masuk ke stadion. Namun, upaya tersebut terkadang masih kurang efektif karena masih sering ada oknum yang menyelundupkan senjata ke dalam stadion. Memang perlu adanya pembagian tingkat keamanan dalam satu pertandingan. Seperti pengawasan dan koordinasi dari pihak keamanan dan panitia pelaksana pertandingan. Hal yang paling mendasar adalah soal tiket pertandingan yang mampu berdampak besar. Bagaimana tiket dapat menjadi sebuah sumber data (database) para suporter sepak bola, sehingga mudah melakukan pengawasan dan meredam tindakan kriminal. Hal tersebut perlu diiringi dengan adanya syarat dan ketentuan, serta diberlakukannya sanksi-sanksi tegas dari panitia pelaksana maupun pihak keamanan dalam pertandingan (Akran 2019). Di sisi lain, panitia pertandingan dan pihak keamanan mampu memaksimalkan tiket untuk mengakomodasi suporter sepakbola agar pertandingan lebih kondusif. Upaya dapat dilakukan dengan mengadakan pemberantasan calo, oknum-oknum panitia maupun pihak keamanan dalam menyaring penonton sepakbola yang masuk ke tribun. Kesalahan-kesalahan teknis tersebut dapat berujung kepada suporter sepakbola di Indonesia yang menjadi liar di stadion, bahkan tidak jarang menjadi tindak kriminal. Tiket pertandingan merupakan hal yang krusial dalam pertandingan persebelasan sepakbola di Indonesia, sebab berpotensi menjadi konflik apabila jumlah kuota suporter tamu yang tak sesuai (Akran 2019).

\section{Kesimpulan}

Dari hasil penelitian dapat disimpulkan bahwa hooliganisme telah berkembang dalam suporter sepak bola di Indonesia. Berawal di daratan Inggris pada akhir abad ke-19, terutama pada tahun 1898. Tindakan hooliganisme ditandai dengan para suporter muda di Inggris yang secara liar melakukan perilaku kekerasan dan destruktif di pertandingan sepak bola. Memasuki era globalisasi, 
informasi dari seluruh dunia dapat diperoleh dengan mudah oleh masyarakat Indonesia, terutama dengan berkembangnya teknologi media dan informasi. Para suporter sepak bola di Indonesia, mulai melakukan duplikasi dengan meniru gaya perilaku para hooliganisme di Inggris. Hal tersebut dibuktikan dengan ditirunya gaya berpakaian, serta cara mereka mendukung klub kebanggaan mereka. Akan tetapi, bersamaan dengan peniruan hooliganisme di Indonesia, hal tersebut membawa pengaruh-pengaruh negatif dalam tindakan para suporter sepakbola. Contoh dari hal negatif yang diikuti oleh para suporter sepak bola di Indonesia adalah tindakan anarkis para suporter. Meskipun pada dasarnya tidak terlalu mendapat pengaruh dari hooliganisme asal Inggris, tetapi hal tersebut juga mencirikan jika suporter sepak bola di Indonesia memiliki kesamaan dengan para hooligan di Indonesia. Hal tersebut semakin menjadi setelah kemunculan film 'Green Street Hooligans' yang cukup mempengaruhi para suporter sepak bola di Indonesia. Melalui film tersebut, para suporter Indonesia mulai meniru para hooligan yang digambarkan di dalam film tersebut, termasuk kekerasan yang dilakukan.

Hal lain yang patut dilihat mengenai motif kekerasan suporter di Indonesia pada dasarnya didasari oleh motif kedaerahan. Faktanya, kelompok suporter sepak bola terbentuk oleh kesamaan identitas, seperti daerah asal dan bahasa. Hal tersebut dibuktikan dengan adanya suporter Persib Bandung yang didominasi oleh masyarakat Jawa Barat dan masyarakat Sunda, suporter Persija Jakarta yang didominasi oleh warga D.K.I. Jakarta, serta suporter Persebaya Surabaya yang didominasi oleh warga asal Surabaya. Motif kedaerahan tersebut yang kemudian mendorong tindakan rasial dalam suporter sepak bola di Indonesia. Salah satu dampaknya adalah banyaknya korban jiwa dari berbagai pihak kelompok suporter diakibatkan tensi antar-suporter tersebut. Pencegahan dapat dilakukan melalui beberapa upaya, baik dalam tingkat nasional atau transnasional. Upaya secara nasional dapat dilakukan dengan penanaman kebijakan ticketing yang lebih baik, guna mendorong efektivitas pengawasan dan tindakan kriminal selama pertandingan. Upaya bersama secara transnasional telah dilakukan dalam beberapa acara pertandingan sepak bola yang melibatkan beberapa tim dari berbagai negara di Eropa. Pembentukan acara antar-tim diharapkan mampu meredam intensitas kekerasan atau hooliganisme antar-kelompok suporter. 


\section{Daftar Pustaka}

\section{Buku dan Bagian dari Buku}

Cawthorne, N. (2012). Football Hooligans. New York: Constable \& Robinson.

Frosdick, S., \& Marsh, P. (2005). Football Hooliganism. Portland: Willan.

Hopkins, M., \& Treadwell, J. (2014). Football Hooliganism, Fan Behaviour and Crime: Contemporary Issues. New York: Palgrave Macmillan.

Ritzer, G. 2010. Globalization: A Basic Text. New Jersey: WileyBlackwell.

Ross, M. H. 2007. Cultural Contestation in Ehtnic Conflict. Cambridge: Cambridge University Press.

\section{Jurnal dan Jurnal Daring}

Ayuningtyas, P. 2009. "Viewers and Identity Consciousness: The Analysis of the Responses of Green Street's Viewers”. Lingua Cultura, 3 (2): 138-145.

Ghafouri, F., Mirzaei, B., Hums, M. A., \& Honavar, A. 2009. "Effects of Globalization on Sport Strategies". Brazilian Journal of Biomotricity, 3 (3): 261-270.

Giulianotti, R., \& Robertson, R. 2004. "The Globalization of Football: A Study in the Glocalization of the 'Serious Life". The British Journal of Sociology, 55 (4): 545-568.

Henderson, T. 2011. "The English Premier League's Home Grown Player Rule under the Law of The European Union”. Brooklyn Journal of International Law, 37 (1): 258-290.

Jan, M. 2009. "Globalization of Media: Key Issues and Dimensions". European Journal of Scientific Research, 29 (1): 66-75.

Steen, R. 2016. "Interwoven Tragedies: Hillsborough, Heysel, and Denial”. Sports in Society, 19 (2): 254-266.

Therborn, G. 2000. "Globalizations: Dimensions, Historical Waves, Regional Effects, Normative Governance”. International Sociology, 15 (2): 151-179. 
Wingkelman, M. J. 1994. "Cultutral Shock and Adaption". Journal of Counselling \& Development, 73 (2): 121-126.

Wright, G. 1999. "Sport and Globalization". Olympic Review, 26 (29): 17-21.

\section{Artikel Daring}

Akran, R.A. 2016. Permusuhan Antar Suporter Sepakbola di Indonesia Terlalu Barbar! [daring] di https://panditfootball. $\mathrm{com} /$ cerita/206667/RAI/161110/permusuhan-antarsuporter-sepakbola-di-indonesia-terlalu-bar-bar [Diakses 3 Februari 2020].

History. 2009. Christopher Columbus. [daring] di https://www. history.com/topics/exploration/christopher-columbus [Diakses pada 29 Desember 2019].

History. 2010. The Space Race. [daring] di https://www.history. com/topics/space-race [Diakses 29 Desember 2019].

Ramdhani, D. 2017. Kronologi Pengeroyokan Ricko Bobotoh Persib yang Meninggal Dunia [daring] di https://regional.kompas. com/read/2017/07/28/07535911/kronologi-pengeroyokanricko-bobotoh-persib-yang-meninggal-dunia?page $=$ all . [Diakses 20 Januari 2020].

Simbolon, H. 2018. Headline Kasus Pembunuhan Haringga Sirla Korban Kebencian yang Mengakar [daring] di https:// www.liputan6.com/news/read/3654973/headline-kasuspembunuhan-haringga-sirla-korban-kebencian-yangmengakar [Diakses 20 Januari 2020].

\section{Lain-Lain}

Akran, R. A. 2019. Sejarah Hooliganisme di Inggris dan Indonesia. (F. Hendika, Interviewer).

Almuttaqi, Ibrahim. 2016. "Countering ISIS in Southeast Asia: ASEAN's Efforts at the Regional Level” paper presented in Talking ASEAN on "Countering ISIS in Southeast Asia" on 18 February 2016 in the ASEAN Studies Program The Habibie Center, Jakarta. 
Aunnurahman. 2019. Sejarah Sepakbola di Inggris dan Indonesia. (F. Hendika, Interviewer).

Carnibella, G., Fox, A., Fox, K., McCann, J., Marsh, J., \& Marsh, P. 1996. Football Violence in Europe. Social Issues Research Centre.

Deriemaeker, A., \& Maere, D. P. 2016. Football Hooliganism in England. University of Antwerp.

Spaaij, R. 2005. The Prevention of Football Hooliganism: A Transnational Perspective. Amsterdam: Amsterdam School for Social Science Research.

Scraton, P. 2009. Hillsborough: The Truth. Edinburgh: Mainstream Publishing Company.

Vreeswijk, M. 2016. Identity Politics of Football Supporters in the Era of Globalization and Commodification: a Dutch Case Study at FC Twente. Dspace Library. 